ASEE Session 1339

\title{
Baseball Stadium Design: Teaching Engineering Economics and Technical Communication in a Multi-Disciplinary Setting
}

\author{
Kevin Dahm and James Newell \\ Rowan University, Glassboro, NJ
}

\begin{abstract}
Rowan University's Sophomore Engineering Clinic provides students with an introduction to engineering design and formal training in technical communication. The course is team taught by faculty from the College of Communications and the College of Engineering. During the past two years, a very successful Sophomore Clinic module on economic design of a baseball stadium has been conducted. Students are presented with a list of possible stadium designs, in which the major parameters are cost and seating capacity, and are challenged to determine which best meets the team's needs. Working in teams of 3-4, they analyze data to quantify the effect of team payroll on won-loss record, which in turn affects ticket sales and merchandising revenues. They produce an optimized economic strategy for running the team, the cornerstone of which is the stadium selection. To support this project, engineering classroom instruction is devoted to introducing the design process ( 2 weeks), fundamentals of engineering economics ( 6 weeks) and basic statistics ( 1 week). Concurrently, communications faculty members train students in public speaking.
\end{abstract}

At the end of the semester, students present their design in a simulated business meeting to engineering faculty, who portray the owners of the team, and communications faculty, who portray city officials. Students are thus challenged to convince two groups who may have very different agendas that their design is best. Consequently, the module provides a practical exercise in persuasive speaking that nicely complements the more familiar technical seminar.

Introduction: The Rowan University College of Engineering has a hallmark 8-semester, interdisciplinary engineering clinic sequence, intended to give students practical experience in engineering research and design, as well as technical communication. The full eight-semester sequence has been described previously in detail. ${ }^{1-4}$

Students in all four Rowan engineering disciplines (chemical, civil, electrical, and mechanical) take the Sophomore Engineering Clinic, a course team taught by faculty from the College of Engineering and the College of Communications. Each week, three one hour and fifteen minute meetings are devoted to classroom instruction on technical communication- technical writing in the fall semester, public speaking in the spring semester. In addition, a three-hour lab session each week is devoted to engineering topics. Students work in multi-disciplinary teams of 3-4 on semester-long, open ended design problems. Deliverables are graded jointly by Engineering and Communications faculty, with technical merit and effectiveness of communication weighted equally. 
This paper describes a Sophomore Clinic module on the economic design of a baseball stadium, conducted in the spring semesters of the 98-99 and 99-00 academic years. Students from all four Rowan engineering disciplines took the module. Pedagogical goals of the project included:

- Developing public speaking skills in a realistic, business setting

- Giving students practical experience with open-ended design problems

- Developing teamwork skills

- Providing instruction in engineering economics and statistics

This paper will describe the project in detail and discuss how it addresses each of these pedagogical goals.

Project Description: Students worked in teams of 3-4 to select a new stadium for a local major league baseball team, from the list of options shown in Table 1.

Table 1: Costs Associated with Candidate Stadium Designs.

\begin{tabular}{|c|c|c|}
\hline Seating Capacity & Cost of Construction & Annual Upkeep \\
\hline 70,000 & $\$ 350$ million & $\$ 16$ million \\
\hline 60,000 & $\$ 300$ million & $\$ 14$ million \\
\hline 45,000 & $\$ 250$ million & $\$ 12$ million \\
\hline 30,000 & $\$ 200$ million & $\$ 10$ million \\
\hline
\end{tabular}

In order to determine which stadium best met the team's needs, students were thus required to project income from ticket sales, which was related to the success of the team by the following specifications, also provided by the instructor:

\footnotetext{
Attendance Information: In the current stadium, even when the team is terrible, it draws a loyal 20,000 fans per home game. The team draws MUCH better when it is doing well, so for each win above 70, you get an extra 1,000 fans per home game. For the purposes of this problem, we will assume the current stadium can last another season or two, but cannot be used beyond that. The new stadium is expected to draw better, especially for the first couple seasons while it is new:
}

FIRST YEAR: 25,000 fans per game, plus 1,000 for each win above 60 . SECOND YEAR: 25,000 fans per game, plus 1,000 for each win above 65 . THEREAFTER: 25,000 fans per game, plus 1,000 for each win above 70 .

Ticket Sales: There are 81 home games per year. Currently, the mean ticket price is $\$ 14$. Fans are used to prices increasing by 50 cents per season- you can budget for this increase without expecting any drop-off in attendance. You can increase ticket prices by more than that if you want, but studies show that attendance will fall by $10 \%$ for every "extra" dollar increase in ticket price.

Also, note that each ticket holder averages an additional $\$ 10$ in food, parking, programs, etc.

The success of the team, in turn, is related to the payroll. Thus, students were provided with information shown in Table 2, which are actual team salaries and won-loss records for the 1998 and 1999 major league baseball seasons. Additional specifications provided by the instructor allowed students to project revenues from other sources such as merchandising and TV/Radio contracts: 
Television and Radio Money: The team will receive $\$ 40$ million in the coming season, increasing by $\$ 3$ million per year for the next 10 years, at which time a new contract will be negotiated.

Merchandising: You can count on \$5 million per year, plus another $\$ 100,000$ for each win above 60.

Thus, the thrust of the design problem was to determine whether or not the increased revenues associated with a winning team would be sufficient to offset the expenses of high payrolls and a larger stadium.

Table 2: Payrolls and Won-Loss Records for all 98 and 99 Major League Baseball Teams.

\begin{tabular}{|l|c|c|c|c|}
\hline Team & $\begin{array}{c}1999 \text { Salary } \\
\text { (In Millions) }\end{array}$ & 1999 Record & $\begin{array}{c}1998 \text { Salary } \\
\text { (In Millions) }\end{array}$ & 1998 Record \\
\hline New York Yankees & $\$ 92.0$ & $98-64$ & $\$ 66$ & $114-48$ \\
\hline Texas Rangers & $\$ 80.8$ & $95-67$ & $\$ 61$ & $88-74$ \\
\hline Atlanta Braves & $\$ 79.3$ & $100-62$ & $\$ 62$ & $106-56$ \\
\hline Los Angeles Dodgers & $\$ 76.6$ & $77-85$ & $\$ 63$ & $83-79$ \\
\hline Baltimore Orioles & $\$ 75.4$ & $78-84$ & $\$ 72$ & $79-83$ \\
\hline Cleveland Indians & $\$ 73.5$ & $97-65$ & $\$ 60$ & $89-73$ \\
\hline Boston Red Sox & $\$ 72.3$ & $94-68$ & $\$ 59$ & $92-70$ \\
\hline New York Mets & $\$ 71.5$ & $97-66$ & $\$ 59$ & $88-74$ \\
\hline Arizona D-Backs & $\$ 70.0$ & $100-62$ & $\$ 32$ & $65-97$ \\
\hline Houston Astros & $\$ 56.4$ & $97-65$ & $\$ 48$ & $102-60$ \\
\hline Chicago Cubs & $\$ 55.4$ & $67-95$ & $\$ 50$ & $90-73$ \\
\hline Colorado Rockies & $\$ 54.3$ & $72-90$ & $\$ 48$ & $77-85$ \\
\hline Anaheim Angels & $\$ 51.3$ & $70-92$ & $\$ 48$ & $85-77$ \\
\hline Toronto Blue Jays & $\$ 48.8$ & $84-78$ & $\$ 34$ & $88-74$ \\
\hline San Diego Padres & $\$ 46.5$ & $74-88$ & $\$ 53$ & $98-64$ \\
\hline St. Louis Cardinals & $\$ 46.3$ & $75-86$ & $\$ 44$ & $83-79$ \\
\hline San Francisco Giants & $\$ 46.0$ & $86-76$ & $\$ 49$ & $89-74$ \\
\hline Seattle Mariners & $\$ 45.3$ & $79-83$ & $\$ 44$ & $76-85$ \\
\hline Milwaukee Brewers & $\$ 43.0$ & $74-87$ & $\$ 32$ & $74-88$ \\
\hline Cincinnati Reds & $\$ 38.0$ & $96-67$ & $\$ 21$ & $77-85$ \\
\hline Tampa Bay Devil Rays & $\$ 37.9$ & $69-93$ & $\$ 27$ & $63-99$ \\
\hline Detroit Tigers & $\$ 37.0$ & $69-92$ & $\$ 19$ & $65-97$ \\
\hline Philadelphia Phillies & $\$ 30.4$ & $77-85$ & $\$ 29$ & $75-87$ \\
\hline Oakland A's & $\$ 25.2$ & $87-75$ & $\$ 22$ & $74-88$ \\
\hline Chicago White Sox & $\$ 24.5$ & $75-86$ & $\$ 35$ & $80-82$ \\
\hline Pittsburgh Pirates & $\$ 23.7$ & $78-83$ & $\$ 14$ & $69-93$ \\
\hline Kansas City Royals & $\$ 16.6$ & $64-97$ & $\$ 36$ & $72-89$ \\
\hline Minnesota Twins & $\$ 15.8$ & $63-97$ & $\$ 25$ & $70-92$ \\
\hline Montreal Expos & $\$ 15.0$ & $68-94$ & $\$ 8.4$ & $65-97$ \\
\hline Florida Marlins & $\$ 14.7$ & $64-98$ & $\$ 15$ & $54-108$ \\
\hline
\end{tabular}

Another important aspect of the project was deciding how the stadium would be paid for. It was specified that the owners of the team had only $\$ 30$ million in cash available, and that they had the option of borrowing an unlimited amount of money at $6 \%$ annual interest. Further, it was specified that the city could be asked to make a contribution of any size to the construction of the stadium.

At the end of the semester, each student group presented its design in a mock business meeting. Meetings were conducted in a conference room with appropriate professional attire. Engineering 
faculty members portrayed the owners of the team, and public speaking faculty members portrayed officials of the city. Each student group was required to present the following:

- Their selection of the stadium, and the rationale for the choice

- A detailed cash flow diagram of revenues and expenses for a planning horizon of at least 10 years

- Specification of how the cost of the stadium would be divided between the city and the team owners

- A detailed, realistic time frame for paying back the loan, if any

- A decision on who would own the stadium- city or team- upon its completion

Students were advised that both the city and the team had an absolute veto on any stadium plan, so their design must appeal to both groups to be effective.

Public Speaking Skills: In recent years, many engineering educators have recognized ${ }^{5-7}$ that technical communication is a vital component of engineering practice and have sought ways to develop these skills in their students. In addition, the new ABET criteria mandates that this will be a priority for all accredited engineering programs ${ }^{8}$. In general, most of a student's experience with public speaking follows the seminar format: a prepared speech of a predetermined length followed by a couple of questions. The authors certainly do not dispute the value of this experience; indeed, each student gave three graded speeches (on topics of the student's choice and unrelated to the Baseball Stadium project) during the course of the semester in Sophomore Clinic. However, the business meeting format of the final presentation is intended to complement this experience, as it differs from the seminar in several important respects:

- It is persuasive, rather than informational, in nature

- It is a team presentation, rather than a seminar given by an individual

- The "audience" participates actively throughout rather than waiting passively until the end

Development of Design Skills: Another recent trend in engineering education is the integration of design experiences into the lower levels of the curriculum, in addition to the traditional senior capstone design course. ${ }^{1,3,8-12}$ Such integration is desirable because it provides more time for these crucial skills to develop, and because it provides a practical context that helps students appreciate the significance and interrelationships of the many topics covered in their technical education.

This project is not at all technically esoteric; it is readily understandable and manageable for sophomores. However, it provides a substantial design challenge because of the conflicting agendas. It was stated in class that the team's primary agenda was to make money, regardless of team success. The given specifications were crafted so that a design with minimal payroll and small stadium would prove to be most profitable. However, the city's primary agenda was to foster commerce in the area around the stadium and enhance the prestige of the city, and these ends were best met by a winning team. This motivated the students to approach the problem in a spirit of creativity and compromise, and insured that the design problem would be open-ended with no provably optimal solution. 
To support the students' design efforts, the first two weeks of lab time were devoted to engineering design principles and miniature design problems, as well as techniques such as the House of Quality. ${ }^{13}$

Developing Teamwork Skills: Students worked in groups of 3-4. An important feature of the problem is that the decisions that need to be made (size of stadium, source of funding etc.) are too closely interrelated to be divisible. This helps insure that students will go through a true team experience. The team can certainly identify many tasks, such as specific calculations, which can be assigned to an individual. However, the team must interact and compare notes in order to make the critical decisions; there is no real way for members to simply work independently on separate aspects of the problem and then combine their efforts at the end.

Exposure to Engineering Economics and Statistics: In order to compare meaningfully the four possible stadium designs, students needed to possess a working knowledge of such engineering economics principles as present worth and rate of return and techniques such as sensitivity analysis. Six weeks of classroom instruction were devoted to instruction and problem-solving exercises in engineering economics. Each meeting was concluded with a discussion of how the new principles introduced could be utilized in the baseball stadium design project.

As indicated in the Project Description section, the instructors contrived most problem specifications for simplicity and convenience. However, it was considered desirable to include one aspect to the problem that required engineering approximations, and this was quantifying the relationship between team payroll and won-loss record. One week of class time was devoted to basic statistical techniques such as linear regression. The College of Engineering does not require students to take a full course on statistics, but recognizes that basic statistics are frequently employed by engineers, and thus inclusion of this instruction into a multi-disciplinary sophomore course is a benefit to the program.

Summary and Conclusions: The Baseball Stadium Design project described here proved to be a popular and highly successful vehicle for introducing principles of engineering economics, engineering design and technical communication into the sophomore year for students of all engineering disciplines. Student feedback on the module was very positive. When asked to rate the module overall on a scale from 1-5, two classes of students gave mean ratings of 4.33 and 4.13. Specific student comments included that the project was enjoyable and that the business meeting format of the final presentation was a very realistic and useful exercise.

\section{References}

1. J. Marchese, R. Hesketh, and K. Jahan, Design in the Rowan University Freshman Engineering Clinic. Proc. Conf. Amer. Soc. Eng. Edu., Session 3225, (1997).

2. J. Schmalzel, A. Marchese, and R. Hesketh, What's Brewing in the Engineering Clinic?. Hewlett Packard Engineering Educator. 2(1), 6 (1998). 
3. J. Mariappan and A. Marchese, TQM Approach to Design in the Sophomore Engineering Clinic. Proceedings of the 1998 International Mechanical Engineering Congress, November, (1998).

4. J. Newell, A. Marchese, R. Ramachandran, B. Sukumaran and R. Harvey, Multidisciplinary Design and Communication: A Pedagogical Vision. International Journal of Engineering Education, 15, 5 (1999).

5. Bakos, J. D., "A Departmental Policy for Developing Communication Skills of Undergraduate Engineers," Journal of Engineering Education, vol. 75, p. 101 (November 1986).

6. $\quad$ Elbow, P., "Teaching Thinking by Teaching Writing," Phi Delta Kappan, p. 37, (1983).

7. Newell, J. A., D. K. Ludlow, and S. P. K. Sternberg, "Progressive Development of Oral and Written Communication Skills across an Integrated Laboratory Sequence," Chemical Engineering Education, vol. 31(2), p. 116 (1997).

8. "Engineering Criteria 2000: Criteria for Accrediting Programs in Engineering in the United States," 3rd Ed., Engineering Accreditation Commission, Accreditation Board for Engineering and Technology, Inc., Baltimore, MD, 1999, http://www.abet.org/eac/eac.htm.

9. L. G. Richards and S. Carlson-Skalak, "Faculty Reactions to Teaching Engineering Design to First Year Students", Journal of Engineering Education, Vol. 86, No. 3, pp. 233-240, July 1997.

10. ASME, Innovations in Engineering Design Education: Resource Guide, American Society of Mechanical Engineers, New York, 1993.

11. R. H. King, T. E. Parker, T. P. Grover, J. P. Gosink, N. T. Middleton, "A Multidisciplinary Engineering Laboratory Course", Journal of Engineering Education, Vol. 88, No. 3, pp. 311-316, July 1999.

12. S. S. Courter, S. B. Millar and L. Lyons, "From the Student's Point of View: Experiences in a Freshman Engineering Design Course", Journal of Engineering Education, Vol. 87, No. 3, pp. 283-288, July 1998.

13. S.W. Field and K .G. Swift, Effecting a Quality Change: An Engineering Approach. Wiley and Sons, NY, (1996).

\section{Kevin Dahm}

Kevin Dahm is an Assistant Professor of Chemical Engineering at Rowan University. He received his Ph.D. in 1998 from Massachusetts Institute of Technology. Prior to joining the faculty of Rowan University, he served as an Adjunct Professor of Chemical Engineering at North Carolina A\&T State University. He also served for one year as a Postdoctoral Researcher at the University of California at Berkeley, where he assisted in the development of ModelLA, a process simulation software package for use in the undergraduate chemical engineering curriculum.

\section{James Newell}

Jim Newell is an Associate Professor of Chemical Engineering at Rowan University. He currently serves as Secretary/Treasurer of the Chemical Engineering Division of ASEE and has won a Dow Outstanding New Faculty Award. His research is in High Performance Polymers and integrating communication skills through the curriculum. 